Indonesian Journal of Theology 3/2 (December 2015): 136-155

\title{
MENGHAYATI KEMBALI IMAN KRISTEN LEWAT ANATEISME
}

\author{
Suarbudaya Rahadian
}

\begin{abstract}
With this essay, I aim to provide an alternative way of embracing Christian faith in this postmodern era, by considering both Richard Kearney's concept of anatheism as well as Slavoj Zizek's radical materialism. With the death of the God of ontotheology-as accomplished by modern atheism-Kearney posits anatheism to desribe a further experience of faith that "rebounds" back to God. As such, it assumes a new dimension of encounter with (a/the) postonthotheological God by means of a "wager of faith." In contrast to this God-ward return, the radical materialism of Slavoj Zizek's theological approach foregrounds the very absence of an "absoluteyet-fragile" God within secular, public space. This paper will outline also my own proposal for leveraging nihilism as constructive dialectic for refining and amplifying Christian faith within the site of struggle that is the contemporary postmodern era.
\end{abstract}

Keywords: ontotheology, wager, fragility, hospitality, anatheism.

\begin{abstract}
Abstrak
Lewat tulisan ini penulis hendak menawarkan jalan lain untuk menghayati iman Kristen di era pascamodern melalui konsep anateisme dari Richard Kearney dan materialisme radikal Slavoj Zizek. Anateisme adalah pengalaman beriman kembali kepada Allah, setelah kematian Allah ontoteologi yang sudah ditangkal oleh ateisme modern. Anateisme Kearney mengandaikan perjumpaan dengan Allah pascaontoteologi di dalam imajinasi baru tentang pertaruhan iman (wager of faith) di hadapan sang lain sebagai jalan baru untuk kembali kepada Allah. Sedangkan materialisme radikal dari pendekatan berteologi Slavoj Zizek menampilkan dimensi absennya Allah yang absolut sekaligus rapuh (Absolute fragile) dalam ruang publik yang sekuler. Tulisan ini juga akan memaparkan catatan penulis tentang
\end{abstract}


bagaimana nihilisme dapat dipandang sebagai dialektika konstruktif yang memperkaya dan mengamplifikasi penghayatan iman Kristen dalam pergumulan kontemporer di era pascamodern.

Kata-Kata Kunci: ontoteologi, resiko, kerapuhan, keramahtamahan, anateisme

\section{Pendahuluan}

Salah seorang filsuf Barat abad 20 yang menggeluti wacana postmodern, Jean Francois Lyotard, pernah berkata bahwa salah satu ciri datangnya era postmodernisme ditandai ketika ranah pengetahuan (knowledge) digugat karena adanya ketidakpercayaan terhadap metanarasi (metanarrative) atau narasi besar (grand narrative). ${ }^{1}$ Lyotard mengatakan bahwa selama era modern ilmu pengetahuan ilmiah atau sains, sebagai salah satu wacana, mengklaim dirinya sebagai satusatunya jenis pengetahuan yang valid. Namun sains, menurut Lyotard, tak dapat melegitimasi klaim tersebut oleh karena ternyata aturan main sains bersifat inheren serta ditentukan oleh konsensus para ahli (ilmuwan) dalam lingkungan sains itu sendiri. Sains kemudian secara tak terhindarkan mesti melegitimasi dirinya dengan merujuk pada suatu meta-wacana; secara konkret sains melegitimasi dirinya dengan bantuan beberapa narasi besar seperti dialektika Roh, hermeunetika makna, dan emansipasi subyek yang rasional. Lantas menurut Lyotard, siapakah yang memberi tempat bagi metanarasi ini untuk ada disana menjadi hakim bagi seluruh proses legitimasi kebenaran ini? Bukankah ini merupakan sebuah permainan kuasa yang perlu kita pertanyakan? ${ }^{2}$

Di tengah berbagai skeptisisme akan metanarasi ini, bagaimana penghayatan iman Kristen bisa memiliki kesempatan hidup di era pascamodern ini? Terlebih jika disadari bahwa iman Kristen senantiasa memformulasikan iman di dalam sebuah tata rasionalitas tertentu yang mendaku memiliki pandangan dunia yang universal dan koheren. Apakah penghayatan iman Kristen di era sekuler postmodern dimungkinkan ketika dihadapkan dengan berbagai kontestasi klaim jawaban absolut bagi pertanyaan eksistensial soal makna hidup, kematian, etika, nilai manusia dan masalah-masalah kebudayaan lainnya? Apakah iman Kristen masih masuk akal serta mungkin untuk dijalani di tengah beragam kontestasi narasi kecil mengenai moral,

1 Bambang Sugiharto. Postmodernisme, Tantangan bagi Filsafat (Yogyakarta: Kanisius, 1996), 10.

2 Ibid., 11. 
etika, dan bahkan klaim pencarian makna kehidupan dari agamaagama?

Pertanyaan ini coba dijawab lewat pergumulan panjang oleh Richard Kearney, seorang filsuf dan teolog bidang filsafat agama di Boston College. Kearney memulai perjalanan iman ini ketika perjalanan iman Protestan miliknya menghadapi tantangan kontemporer. Kearney mencoba merumuskan ulang penghayatan iman Kristen yang melampaui rumusan formulasi rasionalis kaku dan rigid. Hal ini dilatarbelakangi oleh perjumpaan dirinya, di satu sisi, dengan kebangkitan fundamentalisme agama-agama di abad 20 yang rigid, kaku, dan keras kepada yang lain. Kemudian, di sisi lain, ia juga berjumpa dengan kebangkitan neo-ateisme ${ }^{3}$ yang tidak kalah garang menyerang agama dan keyakinan kepada Allah.

Di tengah-tengah kegamangan dan pergumulannya ini, Kearney tiba pada kesimpulan bahwa pada akhirnya percakapan tentang Allah mestilah menjadi percakapan yang melampaui soal-soal ontoteologi. ${ }^{4}$ Percakapan mengenai ontoteologi mengandaikan bahwa Allah adalah ada yang ultimat, padahal ada pada dirinya sendiri (das ding an sich) selalu merupakan bagian dari kontingensi ruang, waktu, dan sejarah yang terbatas dan terprediksi dalam telos (tujuan). Jika Allah adalah ada yang ultimat maka Allah terkontingensi dan ini menjadikannya sebuah berhala dan bukan lagi Allah. ${ }^{5}$

\section{Irelevansi Ontoteologi di Hadapan Penderitaan Manusia dan Ketidakpercayaan Pada Allah}

Secara etimologi kata ontoteologi merupakan gabungan dari tiga kata, yaitu kata ta onta, theo dan logy. Kata ini merupakan bentukan dari kata ontologi yang mendapat sisipan kata theo. Secara bahasa, ta onta berarti ada (being), sedangkan theo berarti Tuban, dan logy berarti

${ }^{3}$ Menurut Internet Encyclopedia of Philosophy, "The New Atheists are authors of early twenty-first century books promoting atheism. These authors include Sam Harris, Richard Dawkins, Daniel Dennett, and Christopher Hitchens. The "New Atheist" label for these critics of religion and religious belief emerged out of journalistic commentary on the contents and impacts of their books. A standard observation is that New Atheist authors exhibit an unusually bigh level of confidence in their views. Reviewers have noted that these authors tend to be motivated by a sense of moral concern and even outrage about the effects of religious beliefs on the global scene. It is difficult to identify anything philosophically unprecedented in their positions and arguments, but the New Atheists have provoked considerable controversy with their body of work." http://www.iep.utm.edu/n-atheis/ diakses 9 November 2015.

4 Richard Kearney, The God Who May Be: A Hermeneutics of Religion (Bloomington: Indiana University Press, 2001), 32.

${ }^{5}$ Ibid., 45. 
ilmu pengetahuan. Ontologi adalah ilmu pengetahuan tentang ada. Ontoteologi adalah ilmu pengetahuan tentang keber(ada)an Tuhan. Dalam konteks filsafat, pembahasan tentang ada Tuhan dibicarakan dalam ontologi, khususnya dalam konteks metafisika. ${ }^{6}$

Ontoteologi membangun imajinasi mengenai Allah yang beratribut moral yang melampaui kemewaktuan, tidak berubah, superlatif dalam berbagai kebajikan, maha tahu, maha berdaulat, sumber surplus maknawi dan berbagai kualitas-kualitas metaontologis lain yang dilekatkan pada Tuhan.

Menurut Alister McGrath kebutuhan percakapan ontoteologi dalam percakapan mengenai Allah dalam iman Kristen lahir dari situasi zaman pada masa gereja perdana berkembang dan bertumbuh sehingga diperlukan bahasa dan formulasi yang terpahami oleh orang-orang di zaman itu. ${ }^{7}$ Percakapan filsafati adalah bahasa universal di dalam dunia berbahasa Latin di dalam dunia sekitar gereja perdana. McGrath menambahkan bahwa kebutuhan yang lebih bersifat apologetis untuk memberi jawaban dihadapan penderitaan manusia untuk membela keberadaan Allah masih berkutat dalam ruang lingkup abstraksi spekulatif ${ }^{8}$ dalam bentuk teodise (theodicy), menjadikan onteteologi sebagai advokat terdepan bagi iman Kristen untuk bertahan di hadapan skeptisisme yang makin tidak terhindarkan karena kenyataan akan banalitas kejahatan dan penderitaan.

Masalah kejahatan hanya dapat dijawab oleh teodise dan ontoteologi sejauh kejahatan itu ada dalam tatanan dunia konsep. Akan tetapi, di hadapan kejahatan yang banal dan massif, seperti misalnya peristiwa Auschwitz atau tragedi pembantaian pendukung dan organ underbow PKI tahun $1965,{ }^{10}$ pertanyaan dan jawaban ontoteologi untuk

${ }^{6}$ Alister McGrath, Christian Theology: An Introduction (Malden, New Jersey: Blackwell publisher, 2010), 15.

${ }^{7}$ Ibid., 30.

${ }^{8}$ Di hadapan para proponen dan propagandis gerakan ateisme baru seperti Richard Dawkins, Christoper Hitchens, para teolog Protestan dari tradisi Injili, seperti Ravi Zacharias, melawan argumentasi mereka dengan pendekatan pembuktian keberadaan Allah yang bersifat ontoteologis.

9 Istilah theodicy pertama kali digunakan oleh Leibniz pada tahun 1710. Istilah itu berasal dari dua kata Yunani theos (Allah) dan dikaios (adil/benar). Istilah tersebut dikaitkan dengan usaha manusia untuk memahami keadilan dan keb enaran Allah, khususnya dalam masalah dan penderitaan-penderitaan yang terjadi.

10 Pembantaian di Indonesia tahun 1965-1966 adalah peristiwa pembantaian terhadap orang-orang yang dituduh komunis di Indonesia pada masa setelah terjadinya Gerakan 30 September di Indonesia. Diperkirakan lebih dari setengah juta orang dibantai dan lebih dari satu juta orang dipenjara dalam peristiwa tersebut. Pembersihan ini merupakan peristiwa penting dalam masa transisi ke Orde Baru: Partai Komunis Indonesia (PKI) dihancurkan, pergolakan mengakibatkan jatuhnya presiden Soekarno, dan kekuasaan selanjutnya diserahkan kepada Soeharto. 
mempertahankan dan menghayati iman dihadapan penderitaan yang riil dan konkret menjadi tidak berarti dan tidak relevan lagi. ${ }^{11}$ Demikian pula halnya dengan semua penjelasan soal telos kehidupan dan penjelasan filsafati tentang keadilan Allah.

Gagasan mengenai perlu dipeliharanya ontoteologi juga senantiasa hadir karena kebutuhan iman Kristen untuk tampil aktual dan mampu menjawab keberatan-keberatan modernitas ${ }^{12}$ terhadap iman. Gianni Vattimo mengatakan bahwa sejak medieval theology di Abad Pertengahan, era Reformasi Protestan, bahkan sampai masa keemasan Pencerahan (Aufklarung), iman Kristen adalah soal formulasi dan proposisi metafisika rasional yang tidak lain adalah retorika dan sebuah pertempuran kuasa. ${ }^{13}$ Dengan lugas Vattimo mengatakan bahwa sebuah upaya memformulasikan realitas, terlebih realitas transendental, senantiasa merupakan sebuah gerak yang bertendensi mereduksi ${ }^{14}$ kenyataan ke dalam gestur wacana kuasa. ${ }^{15}$ Singkatnya, tidak ada realitas holistik dan obyektif di dalam formulasi teoritis.

Pembantaian dimulai pada Januari 1966 seiring dengan maraknya aksi demonstrasi mahasiswa yang digerakkan oleh Angkatan Darat melalui Jendral Syarif Thayeb dan memuncak selama kuartal kedua tahun 1966 sebelum akhirnya mereda pada awal tahun 1967 (menjelang pelantikan Jendral Soeharto sebagai Pejabat Presiden). Pembersihan dimulai dari ibu kota Jakarta, yang kemudian menyebar ke Jawa Tengah dan Timur, lalu Bali. Ribuan vigilante (orang yang menegakkan hukum dengan caranya sendiri) dan tentara angkatan darat menangkap dan membunuh orang-orang yang dituduh sebagai anggota PKI. Meskipun pembantaian terjadi di seluruh Indonesia, namun pembantaian terburuk terjadi di basis-basis PKI di Jawa Tengah, Timur, Bali, dan Sumatera Utara. Bandingkan, Harold Crouch, The Army and Politics in Indonesia (Ithaca, NY: Cornell University Press, 1978), 65-66 as cited in R. B. Cribb, Gejolak Revolusi Di Jakarta 1945-1949: Pergulatan Antara Otonomi dan Hegemoni (Jakarta: Grafiti, 1990).

11 Philip Yancey, When Life Hurts: Understanding God's Place in Your Pain (Sisters, OR: Multnomah Publishers, 1999), 89.

12 Pertanyaan-pertanyaan modernitas yang dicoba dijawab oleh iman Kristen pada abad ke-18 sampai awal abad ke-20 berkisar soal keabsahan mukjizat, masalah kepastian historisitas dan otentisitas teks-teks Kitab Suci, masalah aksiologis iman dalam pranata masyarakat modern dan kepentingan untuk iman Kristen tetap berpacu di dalam lintasan konformitas dengan sains dan metodologi ilmiah. Bandingkan Linda Woodhead, "Christianity," in Religions in the Modern World (London: Routledge, 2002), 186-193.

13 Gianni Vattimo, The End of Modernity, Jaques Derrida, ed. (Stanford, CA: Stanford University Press,1988), 11.

14 Reduksionisme dapat diartikan sebagai (a) suatu pendekatan untuk memahami sifat dasar hal-hal kompleks dengan menyederhanakannya ke dalam interaksi dari bagian-bagiannya, atau membuat suatu hal menjadi lebih sederhana atau lebih mendasar atau (b) suatu posisi [filsafat filosofis] bahwa sistem yang kompleks tak lain hanyalah penggabungan komponen-komponennya, dan suatu pernyataan tersebut dapat direduksi menjadi pernyataan dari unsur-unsur perseorangan. Hal ini dapat dikatakan sebagai obyek, fenomena, penjelasan, teori, dan pengertian.

15 Vattimo, The End of Modernity, 15. 
Bagi Vattimo kebangkitan para apologet di kalangan Kristen konservatif dan kebangkitan para propagandis ateisme seperti Christopher Hitchens dan kawan-kawannya merupakan tanda bahwa pertarungan pembuktian ada atau tiadanya Allah di ranah ontologi sesungguhnya sedang memperebutkan satu kepentingan yang sama yaitu triumfalisme ideologi untuk memperebutkan pengaruh politik di ruang publik. Baik bagi kaum apologet Kristen ${ }^{16}$ maupun kaum ateis, pertarungan ini adalah tentang bagaimana sang subyek Cartesian ${ }^{17}$ dapat menaklukan konsep Allah (baik itu ada atau tidak) di dalam wacana masing-masing. ${ }^{18}$

Ide tentang kebuntuan percakapan soal subyek Cartesian juga pernah digemakan oleh Thomas J.J. Altizer yang mengatakan:

The interpretative qualities of the idea of the death God can be similarly apprehended. If we are able to say, for example, that God is not Man writ large, to say even that God is a being of transcendence, wholly other than man conceptually and communicatively, then can we not say, in some sense, that, from a buman perspective, God is dead? Or if man used to believe in a transcendent reality in which power and authority was invested but no longer does so, can we not say, in some sense, that God is dead? Or if

16 Apologet Kristen yang terkenal, Ravi Zacharias, misalnya menyatakan bahwa suatu pandangan dunia (world view) haruslah koheren dan mesti secara memuaskan dapat menjawab empat pertanyaan, yaitu asal mula segala sesuatu (primum movens), makna hidup, moralitas, dan nasib akhir. Ia mengatakan bahwa meskipun semua agama besar membuat klaim eksklusif mengenai kebenaran, iman Kristen unik karena mampu menjawab keempat pertanyaan tersebut dengan tuntas. Bandingkan Ravi Zacharias, Walking From East to West: God in the Shadows (Grand Rapids: Zondervan, 2006).

${ }^{17}$ Kita mengenal René Descartes yang dianggap sebagai peneguh kehadiran manusia sebagai "subyek modern" melalui kalimatnya yang amat terkenal, "aku berpikir maka aku ada." Descartes mengenalkan akal atau rasionalitas sebagai alat yang melapangkan manusia mencapai kebenaran atau hakekat kenyataan yang ada di sekelilingnya. Subyek ala Descartes yang kemudian dikenal sebagai "Subyek Cartesian" adalah sosok diri otonom yang memaknai dan memberi arti kondisi lingkungannya lewat suatu proses pikir yang rasional. Descartes menyebut "cogito" alias subyek yang berpikir merupakan dasar kepastian untuk mengetahui realitas. Dengan menyatakan ini, ia sebenarnya menegaskan bahwa manusia, melalui pikirannya yang rasional, adalah "penentu" segala realitas yang ada di sekelilingnya. Kepastian tidak terletak di luar manusia tapi di dalam "cogito." Proses penalaran ini kemudian menghasilkan kesimpulan bahwa kesadaran manusia adalah sumber pengetahuan utama. Rasionalisme Descartes dengan gigih menyebut bahwa pengetahuan diperoleh melalui deduksi dari asas-asas apriori yang ada dalam pikiran manusia.

18 Vattimo, The End of Modernity, 27. 
man used to apprehend God in a primordial form as creator and sustainer, but no longer does so can we not say, in some sense, that God is dead? ${ }^{19}$

Dengan demikian pendekatan yang berkutat semata-mata pada ontoteologi, menurut Kearney, adalah soal percakapan yang idealis demi memenangkan sebuah hasrat kaum modernis yang terdalam: hasrat akan kepastian mutlak. ${ }^{20}$ Untuk itu, menurut Kearney, ontoteologi pada akhirnya hanya membawa kita pada percakapan tentang Allah yang pasti dan secara semu hidup di dalam permainan bahasa yang tidak berurusan dengan realitas di luar subyek. ${ }^{21}$

\section{Nihilisme Sebagai Sesuatu yang Kodrati dari Iman}

Meminjam analisis Jean Baudrillard, apa yang hilang dari percakapan kita mengenai Allah adalah kesadaran bahwa senantiasa ada yang nihil dalam percakapan teologis. Nihilisme ${ }^{22}$ yang dimaksud di sini bukanlah sekadar ketiadaan makna yang dipahami sebagai pasivitas dihadapan gerak sejarah, tapi bicara mengenai keberanian untuk masuk ke dalam resiko (wager) akan kemungkinan-kemungkinan baru dari percakapan mengenai Allah yang luput dari potret ontoteologi. ${ }^{23}$

Menurut Baudrillard manusia kontemporer hidup dalam dunia simulakra (gambar, citra, atau penanda suatu peristiwa yang telah menggantikan pengalaman). Manusia postmodern hidup dalam dunia yang penuh dengan simulasi, tidak ada yang nyata di luar simulasi, tidak ada yang asli yang dapat ditiru. Nilai guna komoditas dan nilai imperatif sebuah produksipun telah digantikan oleh model, kode, tontonan dan hiperrealisme simulasi. Komunikasi lewat media telah membuat orang terjebak dalam permainan simulacra yang tidak berhubungan dengan realitas eksternal.

19 Thomas J.J. Altizer, The Gospel of Christian Atheism (Philadelphia: Westminster Press, 1975), 65.

20 Richard Kearney, Anatheism (New York: Columbia University Press, 2010), 3.

${ }^{21}$ Ibid., 4.

22 Nietzsche menekankan dua bentuk nihilisme: pasif dan aktif. Nihilisme pasif larut dalam euforia matinya transendensi, sementara nihilisme aktif mengambil posisi aktif dalam terus-menerus menciptakan dan menghancurkan transendensitransendensi baru. Nihilisme naif yang dimaksud di sini adalah nihilisme pasif dalam artian Nietzsche, atau yang dengan sinis disebut Baudrillard sebagai orgy. Bandingkan Jean Baudrillard, "Beyond the Vanishing Point of Art," in Post-Pop Art, P. Taylor, ed., Paul Foss, trans. (Cambridge, MA: MIT Press, 1989).

23 Jean Baudrillard, The Illusion of the End (Grand Rapids, MI: University Michigan Press, 1992), 87. 
Kita hidup di dunia simulakra, dunia yang dipenuhi citra atau penanda suatu peristiwa dan telah menggantikan pengalaman nyata. Pendeknya, massa tidak mempunyai realitas sosiologis. Menurut Baudrillard, pertemuan dengan transendensi senantiasa membawa kepada nihilisme yang membawa kepada langkupan (reversality) yang dia sebut sebagai

The only real pleasure in the world is to watch things 'turn' into catastrophe, to emerge finally from determinacy and indeterminacy, from chance and necessity, and enter the real of vertiginious connections, for better or worse, where things reach their end without passing through their means, where events attain their effects without passing through causes. ${ }^{24}$

Bagi Baudrillard nihilisme adalah sebuah panggilan kepada keberserahan dan keterbukaan aktif bagi berbagai kemungkinan baru yang tak terprediksi dari kepercayaan kepada transendensi atau Allah.

Keterlangkupan (reversibility) merupakan sumbangsih Baudrillard untuk melangkup apa yang tampak baku dan konstan; ia merupakan saksi dari komitmen optimis Baudrillard untuk melawan sistem simulakra ${ }^{25}$ ini. Menyikapi ekstrimitas implikasi reversibilitas ini haruslah dengan mentalitas petaruh (gambler). Itu juga alasan mengapa Baudrillard melihat ini sebagai suatu 'permainan' dan 'tantangan' (challenge).

Reversibilitas Baudrillardian adalah suatu permainan di mana kebenaran telah dikosongkan dari makna esensialnya (telos) untuk lantas kemudian direorientasi demi pergumulan yang sekarang dan menyejarah. Dalam permainan ini, dimana-mana tampak kebenaran, tapi kebenaran tidak ada dimana-mana. Kebenaran bukan soal lokasi (topos), tapi dia adalah ruang kosong (void) dalam jeda antar konstruksi. Bergerak mundur dari masa depan ke masa kini, dari yang ontic kepada yang historis dan keseharian. Itu sebabnya nihilisme bukanlah sebuah ekpresi ketidakpercayaan kepada Allah tapi ekspresi ketidapercayaan kepada sesuatu yang difiksasi untuk mendefiniskan Allah. Bagi seorang beriman, yang terengkuh dan dapat diimani hanyalah Allah.

Dalam berbagai narasi perjumpaan para peziarah iman dengan Allah di Alkitab kita dapat menyaksikan bagaimana perjumpaan itu terjadi dalam suasana yang beraroma nihilistik simulakrum. Misalnya saja perjumpaan imaniah Abraham dengan Allah yang hadir sebagai tamu asing di Mamre yang tidak terverifikasi (Kejadian 18:1). Ada juga perjumpaan dan pengutusan Musa melalui epifani di semak belukar di

24 Ibid., 89.

25 Jean Baudrillard, The Mirror of Production, M. Poster, trans. (St. Louis, Missouri: Telos Press, 1975), 124. 
padang Midian di dalam situasi Musa yang void secara politik (Keluaran $3: 1-18$ ). Atau bagaimana dengan perjumpaan Elia dengan Allah dalam kecemasannya dan skeptisismenya yang fatal di gua di gunung Sinai (1 Raja-raja 19:1-8). Atau bagaimana Tomas, seorang murid Yesus, yang meragukan kebangkitan Yesus dan menuntut sebuah uji verifikasi empirik non sensual (sense = inderawi) untuk mencucukan jarinya pada bekas luka Yesus yang bangkit. Namun akhirnya Tomas sampai kepada iman kepada Yesus yang bangkit tanpa pernah sampai menyentuh bekas luka yang terverifikasi itu (Yohanes 20:27-28).

Di dalam kesimpulan buku Simulacra and Simulation, Baudrillard mengatakan bahwa

Outside of medicine and the army, favored terrains of simulation, the affair goes back to religion and the simulacrum of divinity: "I forbade any simulacrum in the temples because the divinity that breathes life into nature cannot be represented." Indeed it can. But what becomes of the divinity when it reveals itself in icons, when it is multiplied in simulacra? Does it remain the supreme authority, simply incarnated in images as a visible theology? Or is it volatilized into simulacra which alone deploy their pomp and power of fascination -- the visible machinery of icons being substituted for the pure and intelligible Idea of God? ? $^{26}$

Dari penjelasan ini dapat dilihat bahwa nihilisme bukanlah sebuah antitesis dari iman. Nihilisme adalah sebuah batas-batas resiko dari iman yang senantiasa melampaui kemampuan verifikasi inderawi dan akali. Nihilisme mengajak kita berpetualang dalam perziarahan penuh pertaruhan (wager) di dalam pengalaman bersama Allah setelah Allah ontoteologi mati.

\section{Berjumpa kembali dengan Allah setelah Allah (anatheism) di dalam pertaruhan (wager)}

Richard Kearney menawarkan kepada para peziarah untuk merengkuh sebuah jalan anateisme; jalan mengulang kembali kepada Allah setelah Allah ontoteologis. Kearney yang dibesarkan dalam tradisi Kristen Protestan di bawah bayang-bayang modernitas yang serba binari sempat mengalami beberapa guncangan iman karena perjumpaan narasi-narasi Kristen dengan narasi modernisme. Namun perjalanannya ke India memberinya perspektif baru untuk mengatasi konflik antara wawasan iman Kristen dan modernitas. Di dalam

26 Jean Baudrilard, Simulacra and Simulation, Sheila Glaser, trans. (Grand Rapids: University of Michigan Press, 1981),157. 
bukunya Traversing Heart, ${ }^{27}$ Kearney menemukan titik balik bahwa secara lintas simbolik, iman dapat kembali dirajut melintasi metanarasi yang seolah-olah tidak terkait itu ${ }^{28}$. Dari sana rupanya cikal bakal rumusan kembali kepada Allah yang imajinatif itu dimulai.

Ada kata ana atau "jalan kembali" di dalam teisme yang diusulkan Kearney. Sebuah jalan terjal berliku untuk kembali menapaki relasi yang baru dengan Allah setelah Allah. ${ }^{29}$ Secara artikulatif Kearney memberikan definisi mengenai anateisme sebagai berikut:

Ana-theism: another word for way of seeking and sounding the things we consider sacred but can never fully fathom or prove. Another idiom for receiving back. what we have given up as if we were encountering it for the first time. Just as Abrabam received back Isaac as gift, having given him up as patriachal project. In short, another way of returning to a God beyond and beneath the God we thought we possed. ${ }^{30}$

Anateisme menurut Kearney, bukanlah sebuah agama baru. Anateisme bukanlah gerakan dialektis dari teisme tradisional menuju dan berakhir pada telos final. Anateisme bukanlah sebuah evolusi sejarah peradaban ala August Comte, yang memiliki metanarasi soal perkembangan masyarakat dari primitif kepada modern lalu lewat kritik sekuler yang mencampurkan berbagai bumbu spiritualitas lokal ala diversitas pascamodern ke dalam ide ini. Anateisme juga bukanlah sebuah periode predikatif dari iman yang anti kepada iman pascarasional ala new age mevement. Dengan tegas Kearney mengatakan, "Anatheism eschews teleology as much as it does archeology. It resist perfect Origins and Ends. ${ }^{31}$ Anateisme menolak ide romantisme soal orisinalitas yang sempurna maupun soal akhir prediktif yang sempurna. ${ }^{32}$

Kata ana dalam anateisme memberi tanda bahwa ini ada sebuah gerakan untuk kembali kepada iman yang beresiko (primordial wager), kepada inagurasi instan yang menginsyafkan kita soal apa sesungguhnya akar iman dan keyakinan kita kepada Allah. Anateisme menandai hadirnya ruang baru bagi para peziarah iman untuk memilih iman dan nir-iman. ${ }^{33}$ Anateisme adalah undangan kepada peninjauan ulang adegan sejarah keimanan kita dengan membuka diri kepada perjumpaan dengan sang Asing, sang Lain, yang kita pilih atau tidak

${ }^{27}$ Richard Kearney Traversing Heart: Journeys of the Inter-Religious Imagination (Leiden: Brill Academic Publishing, 2010), 18.

28 Ibid., 18.

${ }^{29}$ Kearney, Anatheism, 4.

30 Ibid., 3.

31 Ibid., 6.

32 Ibid.

33 Ibid., 7. 
kita pilih untuk kita sebut Allah. Adegan perjumpaan dengan sang Asing inilah yang menjadi inti dari pertaruhan perziarahan seorang anateis yang akan meresikokan diri pada beragam kecemasan karena sifat keterbukaan radikal yang nir-prediktif, atau dalam bahasa Kearney disebut Holy Insecurities. ${ }^{34}$

Cita rasa ketidakamanan ini yang dicoba dibangun oleh anateisme kepada teisme. Kabar baik dari anateisme adalah iman kembali di bawa pada rasa kebebasan yang imajinatif lewat metafora. Metafora adalah transportasi antara diri dan yang lain, sebuah bentuk gerak intersubyektifitas yang memberi kejernihan. Yang asing, yang ada di luar semesta tradisiku, oleh metafora diajukan sebagai kemungkinan (copula) untuk diuji. Apakah sang Lain itu adalah Allah (yang hadir sebagai tamu Kudus) atau apakah sang Asing itu adalah bukan Allah, melainkan sebuah proyeksi dan pra-asumsiku tentang Allah.

Selain bagi teisme tradisional, anateisme juga memberikan ketidakamanan kudus serupa kepada ateisme. Anateisme memberikan gerakan untuk melonggarkan keyakinan dogmatik yang absolut dari ateisme tentang Allah. Anateisme membangun gerakan luwes untuk melonggarkan kepercayaan diri ateisme tentang kepastian ontologis soal ketiadaan Allah. ${ }^{35}$ Anateisme menghargai kontribusi kekuatan emansipatoris dari ateisme kritis sebagai bagian yang memberi kekuatan bagi perziarahan ini. Apa yang anateisme kritik dari ateisme radikal adalah iman buta dan syahadat ateisme yang triumfalistik. ${ }^{36}$

\section{Lima Lipatan Pertaruhan Anateisme}

\section{Lipatan Pertama: Imajinasi}

Menurut Kearney, resiko-resiko (wagers) menjalani anateisme adalah sebuah halo, lingkaran kemuliaan yang melingkupi perziarahan iman. Lipatan yang pertama adalah imajinasi. Sang peziarah mesti diberi kebebasan untuk memilih imajinasi apa yang akan digunakan untuk menghayati berbagai kemungkinan imajinasi teologis dalam melihat sang lain. ${ }^{37}$ Pilihan untuk berimajinasi adalah pilihan untuk melihat beragam potensi kemungkinan yang akan lahir dari sang lain. Kemampuan berimajinasi ini, menurut Kearney, lahir dari pilihan kita untuk menafsirkan dari 'sisi melihat sebagai' (seeing as). Tanpa imajinasi tidak ada keindahan, dan, mengutip kata-kata Dostoyevsky, "hanya

\footnotetext{
34 Ibid., 9.

35 Ibid.,16.

36 Ibid., 18.

37 Ibid., 40.
} 
keindahanlah yang dapat menyelamatkan dunia." ${ }^{38}$ Dengan demikian keselamatan bagi kaum anateis mesti diawali dengan pertobatan dari xenophobia (ketakutan terhadap yang asing) epistemologis kita terhadap Allah, dunia, dan sesama.

\section{Lipatan Kedua: Humor}

Humor adalah kemampuan untuk menghadapi dan mengkomposisi hal-hal yang berlawanan: melihat secara bersamaan kemungkinan dan ketidakmungkinan. ${ }^{39}$ Sebagaimana Sarah yang mandul ketika memasuki kemahnya tertawa saat mendengar kabar bahwa dia akan mengandung seorang anak. Sebagaimana Maria berkata "amin" kepada malaikat Gabriel untuk janji bahwa di dalam rahim seorang remaja Yahudi ini sang Maha Rahim akan di kandung (chora achoraton). ${ }^{40}$

Humor adalah sebuah respons kreatif terhadap enigma (misteri), kontradiksi dan paradoks. Humor menginsyafkan kita bahwa ada batas bagi pengalaman manusia. Humor membuat relasi kita dengan Allah Sang tak terengkuh itu menjadi sebuah komedi ilahi (divine comedy). Sebagaimana akar kata humor yaitu bumus mengingatkan kita bahwa humor, bumility (kemawasdirian), dan bumanity (kemanusiaan) sesungguhnya berbagi sumber yang sama: respons manusia kepada absurditas hidup dihadapan perjumpaan dengan Allah.

Kehidupan Yesus sendiri adalah sebuah komedi ilahi jika mengacu bagaimana sejarah tragis yang berulang mengubah tragedi menjadi komedi. Menurut Kearney, kehidupan Yesus adalah pertunjukan seorang suci yang bodoh (holy fools) yang menggambarkan Allah sebagai penggembala bodoh yang meninggalkan di tengah malam kandang domba, dengan 99 ekor hewan didalamnya, dengan tanpa penjagaan untuk mencari satu domba hilang, yang bahkan hilang dimanapun tidak diketahui. ${ }^{41}$

Humor memberitahukan kepada kita bahwa Allah anateisme adalah Allah yang mempresentasikan dirinya melewati batasan akreditasi kognitif. Yang tertinggi menjadi yang terendah, yang terbesar adalah yang melayani. "Allah memberitahukan kepada saya leluconnya, dan sungguh ajaib, melihatnya tertawa mengajarkan lebih banyak

38 Vladimir Sergeyevich Solovyov and Vladimir Wozniuk, The Heart of Reality: Essays on Beauty, Love, and Ethics (Notre Dame, IN: University of Notre Dame Press, 2003), 18.

39 Ibid., 42.

${ }^{40}$ Kearney, The God Who May Be, 81.

${ }^{41}$ Kearney, Anatheism, 41. 
kepada saya tentang Dia daripada seluruh ayat dalam kitab suci. Engkau tidak tahu harus menangis atau tertawa di hadapan surplus realitas ilahi," kata Meister Eickhart. ${ }^{42}$ Kita menangis atau tertawa dihadapan perihal yang secara jujur tak bisa kita mengerti. Dengan demikian humor adalah lipatan pertaruhan yang tidak bisa dilewatkan ketika berhadapan dengan Allah anateisme.

\section{Lipatan Ketiga: Komitmen}

Gerak ketiga dalam pertaruhan ini adalah komitmen. Respons kita kepada sang lain atau orang asing adalah sebuah keputusan. Ketika kita memilih kita berkomitmen: ini sikapku atau bukan sikapku kepada sang lain. ${ }^{43}$ Keterbukaan kepada imajinasi dan kepada humor secara simultan ditemani oleh momen memilih untuk berkomitmen pada pilihan kita terhadap sang lain. Ini adalah momen komitmen yang dialami Abraham dan para nabi dihadapan momen konversi di hidup mereka. Lingkaran komitmen ini digambarkan Yesus di taman Getsemani untuk memilih kehendak Bapa apapun konsekuensinya, sekalipun Yesus mengalami momen kehilangan iman di Golgota. Perkataan "Allahku, Allahku, mengapa Engkau meninggalkan aku?" adalah sebuah resiko iman sampai Yesus akhirnya berkata "Ke dalam tanganmu kuserahkan nyawaku."

Komitmen dalam pertaruhan anateisme adalah soal janji setia kepada kebenaran eksistensial, sebuah facere veritatem yakni panggilan untuk mewujudkan kebenaran sekalipun kita tidak memahami sepenuhnya apa itu kebenaran. ${ }^{44}$ Seperti seorang anak yang terus berdoa kepada Allah untuk perdamaian dunia sekalipun dia tidak pernah mengerti bagaimana asal-usul peperangan dan bagaimana mengakhirinya. Di dalam pertaruhan anateisme pengejaran akan hasrat untuk kebenaran menjadi komitmen utama ketimbang memformulasi kebenaran.

\section{Lipatan Keempat: Kepekaan untuk Membedakan}

Yang asing tidaklah niscaya yang Ilahi. Ada juga orang asing yang merupakan pembunuh, pencuri, dan pengambil kehidupan. Ada sang lain yang berderma tapi ada sang lain yang berdusta. ${ }^{45}$ Ketukan di

\footnotetext{
42 Ibid., 43.

${ }^{43}$ Kearney, The God Who May Be, 44.

${ }^{44}$ Kearney, Anatheism, 43.

45 Ibid., 44.
} 
pintu gerbang dapat merupakan ketukan dari Allah yang hadir sebagai tamu asing yang mengundang kita untuk makan bersama di rumah kita sendiri; tetapi di lain pihak ketukan pada pintu gerbang bisa juga adalah upaya sang pembunuh, perampok, penjarah, dan pemerkosa, untuk mengelabui kita dan masuk ke dalam rumah untuk membinasakan kita. Oleh karena itu, tidak semua suara asing mesti diterima. Senantiasa perlu ada dialog dengan sang lain untuk mengasah kepekaan kita apakah sang lain ini adalah pembawa damai atau pembawa malapetaka. Ada orang yang merespons sang lain secara keliru sebagai suara Allah, sehingga menggerakan mereka untuk membunuh, merusak, dan merampas. Ada orang-orang seperti Jim Jones, David Koresh, Charles Manson, Osama bin Laden, tetapi ada juga Dorothy day, Nelson Mandela, Desmond Tutu, Martin Luther King Jr., dan sebagainya.

Pertaruhan anateisme terletak dalam kepekaan profetis menyambut panggilan Allah. Itulah menurut Kearney yang membedakan respons kedua kelompok orang tersebut. ${ }^{46}$

\section{Lipatan Kelima: Keramahtamahan}

Pertaruhan untuk berjumpa kembali dengan Allah dalam jalan anateisme dibangun didalam keramahtamahan; kesediaan untuk menjadi tuan rumah bagi orang asing. Kemampuan mengenali sang lain dan mengambil resiko melayaninya. ${ }^{47}$ Dalam hal ini, Kearney hendak menyitir pendekatan Paul Ricoeur mengenai keramahtamahan kepada sang lain. Bagi Ricoeur, keramahtamahan pada sang lain berpangkal dari kepekaan sang diri untuk menyadari dan menerima bahwa ada yang asing di dalam dirinya. ${ }^{48} \mathrm{Hal}$ ini memungkinkan diri menyadari bahwa yang bersemayam di dalam sang Aku sebagai subyek senantiasa memiliki sisi lain yang sangat mungkin belum dikenali. ${ }^{49}$ Perjumpaan baru dengan Allah anateisme dalam keramahtamahan mensyaratkan perlunya disposesi atau ketakmelekatan tentang konstruksi Sang Aku. Sang Aku perlu diinsyafi sebagai performatifitas yang selalu terkonstruksi, senantiasa cair, inkonsisten, berlapis, serta misterius. ${ }^{50}$ Itu sebabnya sang Aku sebagai subyek tak jarang gagal dipahami oleh diri kita sepenuhnya. Tapi kita dipanggil untuk mengasihi sang Aku (diri) yang asing dan tidak sepenuhnya terpahami ini. Dari sanalah

\footnotetext{
46 Ibid., 46.

47 Ibid., 47.

48 Paul Ricoeur, Oneself As Another, Kathleen Blamey, trans. (Chicago: University of Chicago Press), 166.

${ }^{49}$ Ibid., 168.

50 Ibid., 172.
} 
sumber damai sejahtera yang melampaui segala akal dilahirkan. Orang Kristen menghayati ini sebagai karunia Allah; dan ini berarti karunia Allah mencakup keramahtamahan menerima sang lain di dalam diri, yang memungkinkan kita memiliki keberanian untuk menjadi tuan rumah (bost) yang ramah kepada yang asing di luar diri kita.

Keramahtamahan pada yang asing di luar diri kita sesungguhnya di mulai dari keberanian mengasihi dan menghadapi yang asing di dalam diri kita. Di dalam titik krusial inilah anateisme menjadi sangat beresiko karena mempertaruhkan segalanya, bahkan mempertaruhkan batasan kontruksi kewarasan yang biasa kita anut.

\section{Penghayatan Anateisme dalam yang Material}

Pascamodernisme telah memberikan kemewahan bagi terjadinya ruang baru bagi berseminya beragam narasi tanpa didikte oleh satu metanarasi tunggal; sesuatu yang mustahil terjadi dalam pentas modernisme. Tapi lantas apakah di era postmodern ide tidak bisa bertunas di ruang yang material dan menyejarah? Apakah anateisme adalah semata soal interioritas batin umat beragama seperti beragam model spiritualitas kontemporer dalam khazanah postmodernitas yang jauh dari hiruk-pikuk konteks sosial dan politik?

Penulis percaya bahwa anateisme dapat menjadi model keberadaan iman Kristen di masyarakat sekuler postmodern. Anateisme adalah jalan kembali kepada bentuk keberagamaan yang transformatif yang bisa menghidupkan teisme baru (setelah ateisme) dalam ruang publik ${ }^{51}$ melalui apa yang ditawarkan Zizek dalam karyanya The Fragile Absolute.

${ }^{51}$ Gagasan ruang publik atau public sphere merupakan gagasan yang lahir dari pendapat filsuf Jerman, Jürgen Habermas. Habermas memperkenalkan gagasan ruang publik melalui bukunya Strukturwandel der Öffentlichkeit; Untersuchungen zu einer Kategorie der Bürgerlichen Gesellschaft. Edisi bahasa Inggris buku ini, The Structural Transformation of the Public Sphere: An Inquiry into a Category of Bourgeois Society, diterbitkan pada tahun 1989. Menurut Habermas, public sphere dikonsepsionalisasikan sebagai suatu realitas kehidupan sosial di dalam mana terdapat suatu proses pertukaran informasi dan berbagai pandangan berkenaan dengan pokok persoalan yang tengah menjadi perhatian umum sehingga dalam proses tadi terciptalah pendapat umum. Dengan dihasilkannya pendapat umum maka pada gilirannya akan membentuk kebijakan negara dan pada akhirnya akan membentuk suatu tatanan masyarakat secara keseluruhan. Adanya public sphere menyaratkan keaktifan dari warga masyarakat memanfaatkan hak-haknya untuk ikut berpikir terlibat di dalam suatu wacana yang sedang hangat pada hari suatu saat tertentu, khususnya yang berkaitan dengan permasalahan politik. Dalam perkembangan masyarakat yang makin besar maka proses terbentuknya wacana menuju opini publik tadi lalu diantarai oleh media massa. 
Slavoj Zizek, seorang filsuf radikal dan analis kebudayaan populer, mengatakan bahwa warisan ide Kristen mengenai Allah yang dipresentasikan di dalam Yesus Kristus yang menyejarah menjadi sumber radikal yang dapat memberikan harapan bagi ruang publik untuk menjadi sumber kehidupan (bios) yang sakral di ruang publik. Zizek mengatakan

My claim here is not merely that I am a materialist through and trough, and that Subversive Kernell of Christianity is accesible also to a materialist approach; my thesis is much stronger: this Kernell is accesible only through a materialist approach - and vice versa: to become a true dialectical materialist, one should go through the christian experience. ${ }^{52}$

Lantas pengalaman iman Kristen seperti apa yang dimaksud Zizek yang dapat memberikan pengalaman materialis dalam dunia sekular? Zizek percaya bahwa kekristenan dalam bentuk yang paling subversif harus menolak mengatakan bahwa Allah adalah sang lain yang di sana. ${ }^{53}$ Allah Kristen yang transenden sudah semestinya dianggap nihil karena sudah menjadi material di dalam Yesus kristus yang sudah menunjukan pada kita untuk menyangkali Allah yang ada di sana (sebagai the big other) di atas bukit Golgota dalam seruan eli-eli lama sabaktani. ${ }^{54}$

Bagi Zizek pengalaman kembali kepada Allah dalam iman Kristen adalah melihat Yesus yang menjadi ateis di Kalvari. Sebuah kesadaran yang membuat Yesus dalam semangat emansipatoris merengkuh dunia. Dunia yang penuh akan sejarah penderitaan, absurditas, dan beragam kemungkinan yang terbuka

the transcendent God guaranteeing the making of the universe, God as the bidden Master pulling the strings... we get a God who abandons this transcendent position and throws bimself into his own creation, fully engaging himself in it up to dying, so that we, humans, are left with no higher Power watching over us, just with the terrible burden offreedom and responsibility for the fate of divine creation, and thus of God himself. ${ }^{55}$

Di dalam perjumpaan dengan kekristenan yang telah dilucuti dari ide spekulatif tentang Allah yang transendensinya diinsyafi telah meninggalkan kita, terbentuklah ruang kosong (void). Di dalam void

52 Alan Badiou, A Subject To Truth (Minneapolis: University of Minnesota Press, 2003), 6.

53 Ibid., 65.

54 Ibid., 66.

55 Slavoj Zizek, First as Tragedy than as Farce (London: Verso, 2009), 25. 
itulah tubuh Kristus (gereja) yang menyejarah hadir dan bergerak menemukan momentum untuk membuka kemungkinan baru, yaitu kebangkitan. Tanpa transendensi yang absen, tidak perlu ada kebangkitan material dan komunal yaitu Gereja. ${ }^{56}$

Anateisme yang membuka mata kepada sisi subversif dari kekristenan yaitu materialisme radikalnya, menjadi kekuatan dan alasan bagi iman (dengan rasa baru) untuk hadir di ruang publik untuk menyediakan narasi keimananan yang mempenetrasi yang sekular, melalui sekularisasi menuju sekularisme. ${ }^{57}$ Anateisme yang berbasis pada materialisme radikal sadar bahwa iman Kristen yang berpusat pada Yesus Kristus tidak sedang datang untuk memberi imajinasi semata soal makna hidup secara interior dan esoterik, tetapi juga akan menjadi sebuah perjumpaan menubuh yang akan memberi harapan sekaligus kegamangan yang suci soal hidup bersama dalam kebersamaan dan keadaban di ruang publik.

Anateisme di ruang-ruang publik yang sekular akan membawa pengalaman diri kita bertemu beragam wajah, luka, langgam tradisi dalam diri sang lain, sebagaimana sang lain juga menunjukkan dirinya pada kita. Di dalam perjumpaan yang saling mempenetrasilah pergumulan sesungguhnya baru dimulai. ${ }^{58}$ Penghayatan iman Kristen melalui anateisme di dalam ruang publik jelas bukanlah percakapan gampangan dalam forum komunikasi antar umat beragama untuk sekedar mencari common ground kebaikan yang simplisistik, elitis, dan tanpa perjuangan.

Perjumpaan yang gamang ini adalah sebuah realitas banal yang akan melemparkan kita untuk merengkuh sejarah karena kesadaran bahwa dunia sudah dilepaskan tautannya dari Allah sang pengamat kosmik. Ketiadaan Allah ontoteologis mesti di baca sebagai tanda partisipasi Allah yang sudah membuat dirinya absen melalui aksi kenotik yang membuat Allah menjadi miskin agar dunia menjadi kaya, seperti yang diungkapkan Zizek:

God doesn't give what he has, he gives what he is, his very being. That is to say: it is wrong to imagine the divine dispensation as the activity of a wealthy subject, so abundantly rich that he can afford to cede to others a part of his possessions. From a propertheological perspective, God is the poorest of them all: he "bas" only his being to give away His whole wealth is already out there, in creation. ${ }^{59}$

\footnotetext{
56 Ibid., 31.

${ }^{57}$ Kearney, Anatheism,166.

58 Ibid., 180.

59 Zizek, First as Tragedy, 59.
} 


\section{Penutup}

Saya ingin menutup artikel ini dengan menyatakan bagaimana justru lewat nihilisme, kematian Allah ontologis, dan materialisme radikal, kita akan punya imajinasi baru soal penghayatan iman Kristen alternatif yang akan membawa Allah yang mungkin setelah Allah yang pasti dalam ontoteologis itu mati.

Di dalam penghayatan iman yang memberi beragam kemungkinan baru soal kehidupan inilah, kita dimampukan untuk menghidupi sakralitas kehidupan di hadapan kematian, kelahiran yang melahirbarukan kehidupan untuk mengalami surplus ada, yakni hidup yang seutuhnya. ${ }^{60}$

Menurut saya lagi-lagi Zizek dengan cara yang unik dalam leluconnya yang artikulatif menggemakan hal ini. Izinkan saya mengutipnya untuk menutup makalah ini:

The God that we get here is rather like the God from the old Bolshevike joke about a communist propagandist who, after his death, finds himself in bell, where he quickly convinces the guards to let him leave and go to heaven. When the devil notices his absence, he pays a visit to God, demanding that He return to hell what belongs to Satan. However, as soon as he addresses God as "my Lord", God interrupts him: "First, I am not 'Lord', but a comrade. Second, are you crazy, talking to fictions? I don't exist! And third, be short -- otherwise, I'll miss my party cell meeting. ${ }^{11}$

Ini adalah Allah anateisme. Allah yang secara radikal ada dalam kemanusiaan; seorang kawan (Comrade) di antara kita, disalibkan di antara dua orang yang terhukum secara sosial politik. Allah yang bukan hanya tidak eksis secara ontoteologis, tetapi juga yang menyadarinya bahwa ketiadaannya itu lebih berguna bagi dunia. Allah yang menerima kenyataan bahwa dirinya telah dihapus dari yang biasanya dikenali karena membuat gerakan memotong jalur eksistensial ontologis dengan cara sepenuhnya melawat ciptaan lewat cinta yang menubuh, yang secara emansipatoris dan kolektif hadir lewat Roh Kudus dalam dan melalui umatnya.

${ }^{60}$ Kearney, Anatheism, 80-81.

${ }^{61}$ Slavoj Zizek, "Soul of the Party: St Paul Had It Right - Using Religion to Rock the Foundations of Authority." New Statesman. April 1, 2010. 


\section{Tentang Penulis}

Suarbudaya Rahadian adalah Pendeta Jemaat Gereja Komunitas Anugerah Reformed Baptist Salemba dan salah seorang Visiting Pastor Scholar STT Jakarta-2015-2016.

\section{Daftar Pustaka}

Alister McGrath. Christian Theology: An Introduction. Malden, New Jersey: Blackwell Publisher, 2010.

Altizer, Thomas J.J. The Gospel of Christian Atheism. Philadelphia: Westminster Press, 1975.

Badiou, Alan. 2003. A Subject to Truth. Minnesota: University of Minnesota Press, 2003.

Baudrillard, Jean. 1973. The Mirror of Production. Trans, Mark Poster. New York: Telos Press. . Simulacra and Simulation. Trans, Sheila Glaser. Grand Rapids: University of Michigan Press, 1981. . Cool Memories. Paris: Verso Press, 1987. . The Illusion of the End. Trans, Sheila Glaser. Grand Rapids: University of Michigan Press, 1992.

Cox, Harvey. The Secular City: Secularization and Urbanization. Pelican Book, 1966.

Cribb, R. B. Gejolak Revolusi di Jakarta 1945-1949: Pergulatan Antara Otonomi dan Hegemoni. Jakarta: Grafiti, 1990.

Crouch, Harold. "The Army and Politics in Indonesia." The Journal of Developing Areas 13/4 (1978).

Kearney, Richard. The God Who May Be: A Hermeneutics of Religion. Bloomington: Indiana University Press, 2001. - Traversing the Heart: Journeys of the Inter-Religious Imagination. Leiden: Brill Academic Publishing, 2010. . Anatheism. New York: Colombia University Press, 2010.

Ricoeur, Paul. Oneself as Another. Trans, Kathleen Blamey. Chicago: The University of Chicago Press, 1992.

Vattimo, Gianni. The End of Modernity. Ed, Jaques Derrida. Stanford: Stanford University Press, 1998.

Yancey, Phillip. When Life Hurts: Understanding God's Place in Your Pain. Colorado: Multnomah Books, 1999.

Zacharias, Ravi. Walking from East to West: God in the Shadows. Grand Rapids: Zondervan Publishing, 2006. 
Zizek, Slavoj. The Ticklish Subject: The Absent Centre of Political Ontology. London: Verso, 2000. The Puppet and the Dwar: The Perverse Core of Christianity. Cambridge, MA: MIT Press, 2001. . The Fragile Absolute: London Or, Why is the Christian Legacy Worth Fighting For? London: Verso, 2001. . The Parallax View. Cambridge, MA: MIT Press, 2006. . "Soul of the Party: St Paul Had It Right - Using Religion to Rock the Foundations of Authority." New Statesman. April 1, 2010. 